\title{
Intrinsic and Extrinsic Thymic Adrenergic Networks: Sex Steroid- Dependent Plasticity
}

\author{
Gordana Momčilo Leposavić ${ }^{1 *}$ and Ivan M. Pilipović ${ }^{2}$ \\ ${ }^{1}$ Department of Physiology, Faculty of Pharmacy, University of Belgrade, Belgrade, Serbia, ${ }^{2}$ mmmunology Research Centre \\ "Branislav Jankovic', Institute of Virology, Vaccines and Sera "Torlak", Belgrade, Serbia
}

OPEN ACCESS

Edited by:

Daniella Areas Mendes-Da-Cruz, Fundação Oswaldo Cruz (Fiocruz),

Brazil

Reviewed by: Arturo Ortega,

Centro de Investigación y de Estudios Avanzados del Instituto Politécnico Nacional (CINVESTAV-IPN), Mexico Wei-Jiang Zhao,

Shantou University, China

*Correspondence:

Gordana Momčilo Leposavić gordana.leposavic@pharmacy.

bg.ac.rs

Specialty section:

This article was submitted to Neuroendocrine Science,

a section of the journal

Frontiers in Endocrinology

Received: 22 November 2017 Accepted: 11 January 2018 Published: 30 January 2018

Citation:

Leposavić GM and Pilipović IM (2018) Intrinsic and Extrinsic Thymic

Adrenergic Networks: Sex Steroid-Dependent Plasticity.

Front. Endocrinol. 9:13. doi: 10.3389/fendo.2018.00013
The thymus is sexually differentiated organ providing microenvironment for T-cell precursor differentiation/maturation in the major histocompatibility complex-restricted self-tolerant $T$ cells. With increasing age, the thymus undergoes involution leading to the decline in efficacy of thymopoiesis. Noradrenaline from thymic nerve fibers and "(nor) adrenergic" cells is involved in the regulation of thymopoiesis. In rodents, noradrenaline concentration in thymus and adrenoceptor $(A R)$ expression on thymic cells depend on sex and age. These differences are suggested to be implicated in the development of sexual diergism and the age-related decline in thymopoiesis. The programming of both thymic sexual differentiation and its involution occurs during the critical early perinatal period and may be reprogrammed during peripubertal development. The thymic (re) programming is critically dependent on circulating levels of gonadal steroids. Although the underlying molecular mechanisms have not yet been elucidated fully, it is assumed that the gonadal steroid action during the critical perinatal/peripubertal developmental periods leads to long-lasting changes in the efficacy of thymopoiesis partly through (re) programming of "(nor)adrenergic" cell networks and AR expression on thymic cells.

Keywords: thymic noradrenergic innervation, noradrenaline-synthesizing thymic cells, adrenoceptors, sex steroids, thymic involution, thymic programming/reprogramming

The thymus is organ in which $\mathrm{T}$ cells are continually generated in a highly dynamic process comprising T-cell receptor (TCR) gene rearrangement, lineage commitment, and selection (1). These processes are linked to distinct rates of proliferation and cell death by apoptosis (1). With increasing age, the thymus atrophies and declines in functions, the phenomenon termed involution (2). Consequently, thymic generation of naïve $\mathrm{T}$ cells declines $(2,3)$. This leads to the shrinkage of peripheral TCR repertoire and the expansion of memory $\mathrm{T}$ cell compartment, i.e., to the changes covered by the canopy term immunosenescence (3-5). At the clinical level, the immunosenescence is associated with a greater susceptibility to infections $(6,7)$, an impaired response to vaccinations $(8,9)$, and an increased propensity for malignant diseases $(10,11)$. In addition, according to the U.S. Center for Disease Control, approximately $80 \%$ of aged individuals are afflicted with at least one chronic disease as a result of a declination of immune function. Consequently, factors contributing to the thymic involution and mechanisms of their action are becoming the subject of increased interest in the scientific and healthcare communities alike. It should be emphasized that understanding of the mechanisms underlying thymic involution is important not only for moderating the deleterious effects of immunosenescence, but also for envisaging strategies to "rejuvenate" the immune system. It is noteworthy that even in a significant thymic involution thymopoiesis does not cease completely, so it may be enhanced (12). The thymic "rejuvenation" becomes particularly important after exposure 
to chemotherapy, ionizing radiation, and some infective agents (e.g., HIV-1) (13).

There is evidence that (i) early perinatal programming of the thymus is crucial for the development of thymic involution, and consequently the efficacy of immune responses from early life through adulthood (14), and (ii) this phenomenon is sexually dimorphic $(14,15)$. Consistently, sex differences in the organ size, structural organization, and thymopoiesis (14-22), and consequently T-cell immune response $(23,24)$, have been observed. A more rapid thymic involution was found in male compared with female mice (25). Consequently, adult females have the ability to reject allografts more efficiently, a greater ability to combat various viral and bacterial infections, and superior antitumor responses (23).

There are data indicating that the early programming of the thymus development/involution is shaped by genetic, environmental, and hormonal factors (14). The role of genetic factors has been shown in both mice and rats (26-31). These genetically based differences are suggested to be connected to strain differences in susceptibility to various pathologies involving immune mechanisms (26-30). Environmental factors, such as malnutrition, and exposure to endocrine disruptors, in early postnatal life are also shown to influence the pace of thymic involution (32). Alterations in circulating levels of sex steroids in the critical early postnatal developmental "window" may influence not only sexual dimorphism in structural and functional thymic parameters, but also the timing of thymic involution $(15,21,33)$. Furthermore, gonadal steroids may influence sexual dimorphism in thymopoiesis, and the age-related decline in its efficacy through: (i) modulating thymic extrinsic (encompassing noradrenergic nerve fibers) and intrinsic [composed of noradrenaline-synthesizing cells, i.e., "(nor)adrenergic" cells] adrenergic regulatory networks, in terms of their density/noradrenaline content and (ii) adrenoceptor (AR) expression on thymic cells $(34,35)$. In addition, it should be pointed out that the ablation of gonadal steroids during the peripubertal developmental "window" leads not only to short-term increase in thymic weight and enhancement of thymopoiesis, but also to the long-lasting thymic "rejuvenation" (33).

The central goal of this mini review is to summarize recent findings and current knowledge related to the mechanisms of indirect (nor)adrenaline-mediated action of gonadal steroids on the programming/reprogramming of thymic involution, as its action may be easily controlled by many drugs in use for nonimmune indications.

\section{THYMIC EXTRINSIC AND INTRINSIC (NOR)ADRENERGIC REGULATORY NETWORKS}

\section{Thymic Extrinsic (Nor)adrenergic Network}

The thymus receives extensive noradrenergic innervation $(36,37)$. The varicose noradrenergic fibers terminate in close proximity to thymocytes $(37,38)$, and various subsets of thymic non-lymphoid (stromal) cells (38-41). In rodents, noradrenergic fibers appear in the thymus in late embryonic period, and their density increases during prepubertal development $(42,43)$. The data on postpubertal changes in their density are inconsistent (44-50). In advanced age, in rodents of distinct (sub)strains has been observed decrease, increase and lack of changes in thymic noradrenergic nerve fiber density compared with young adult (sub)strain-matched ones (44-50). This inconsistency is most likely linked to (sub)strain and sex-dependent differences in the kinetics of postpubertal changes in thymic noradrenergic innervation. It has also been suggested that the noradrenaline content in thymic nerve fibers, and consequently thymic noradrenaline concentration vary with age (44-50). In addition, both thymic parameters were found to be greater in male than in age-matched female rats (51) (Figure 1).

\section{Thymic Intrinsic (Nor)adrenergic Network}

Many types of mature immune cells synthesize and secrete catecholamines (52-54). The investigations of the expression of tyrosine hydroxylase (TH), the key rate-limiting enzyme in catecholamine synthesis in freshly isolated thymic cells, cultured thymocytes and cells from adult thymic organ culture revealed that thymic cells, including thymocytes, synthetize noradrenaline $(34,51,55)$. TH-immunoreactive cells were found across all thymocyte subsets delineated by CD3 expression levels, but their frequency was highest among the most mature CD $3^{\text {high }}$ thymocytes (51). In addition, TH-immunoreactive cells were observed in various thymic non-lymphoid cell subpopulations $(44,51)$. Their density varies across distinct thymic microenvironments. They are frequent at the medullary side of the corticomedullary junction, whereas their density is moderate and poor in the subcapsular cortex, and intracortically/intramedullary, respectively (51). This is important as various thymic non-lymphoid cell subsets are strategically positioned in particular thymic microenvironments to orchestrate thymocyte differentiation/ maturation (56). TH immunoreactivity was observed in thymic epithelial cells (TECs) $(39,51,57-59)$, macrophages, and dendritic cells $(44,60)$. In TEC population, TH immunoreactivity was found in neural crest-derived thymic nurse cells $(51,57,58)$, type 1 (subcapsular/perivascular), and type 5 (located mainly in corticomedullary region) cells $(39,51,59)$. The density of both lymphoid and non-lymphoid TH-immunoreactive cells was shown to be higher in male than in female rats (51) (Figure 1). In addition, the overall noradrenaline content in thymocytes was found to be greater in male compared with female adult rats (51) (Figure 1). Although studies in rat adult thymic organ and thymocyte cultures suggested that noradrenaline from thymic "(nor)adrenergic" cells is implicated in the fine tuning of thymopoisesis (55), a role for thymic intrinsic adrenergic network in thymic homeostasis is still far from being understood. It is noteworthy that intrinsic (nor)adrenergic cellular networks: (i) have also been identified in some other tissues and (ii) suggested to be particularly important under specific conditions, e.g., following sympathectomy, gonadectomy, chronic stress $(45,61-65)$, as it allows for mainly local regulation of the catecholamine influence $(64,66)$.

\section{AR Expression on Thymic Cells}

To corroborate modulatory role for noradrenaline in the thymus is the expression of ARs on both thymocytes and thymic 


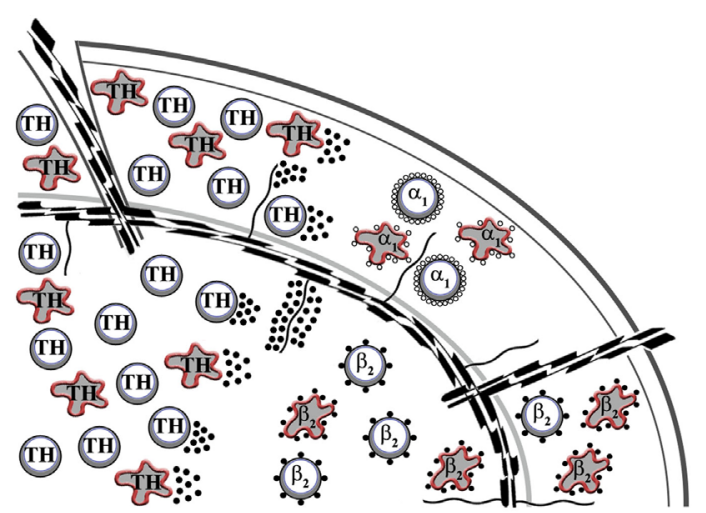

\section{Neonatally androgenized youg adult females}

is Thymic NA level

A Noradrenergic fiber NA content

$\checkmark \mathrm{TH}+$ thymocyte/non-lymphoid cell density

i TH+ thymocyte/non-lymphoid cell NA content

i $\beta$-AR+ thymocyte frequency

$\downarrow$ Thymocyte $\beta_{2}$-AR surface density

$\uparrow \beta_{2}$-AR+ non-lymphoid cell density

$\uparrow$ ? Thymocyte $\alpha_{1}-\mathrm{AR}$ surface density
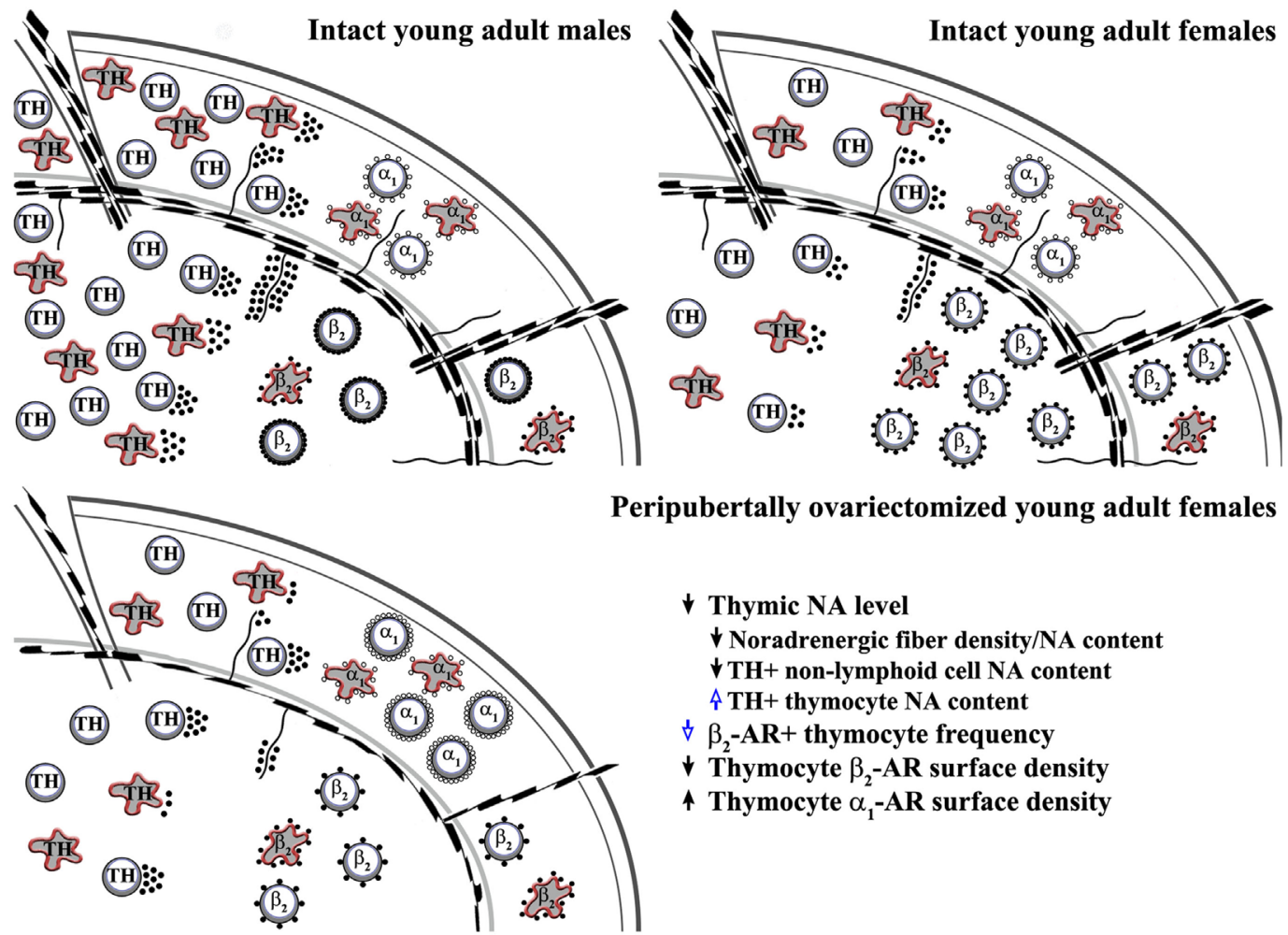

Peripubertally ovariectomized young adult females

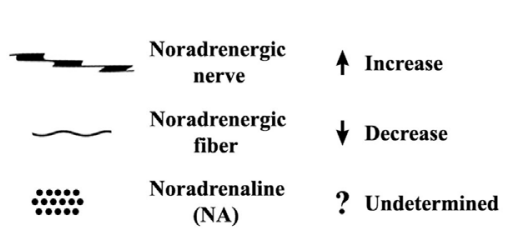

\begin{tabular}{|c|c|c|}
\hline & Thymocyte & Non-lymphoid cell \\
\hline TH-expressing & (II) & TH \\
\hline$\beta_{2}-\mathrm{AR}$-expressing & & \\
\hline$\alpha_{1}$-AR-expressing & & 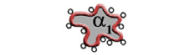 \\
\hline
\end{tabular}

\begin{tabular}{|c|c|c|}
\hline \multicolumn{3}{|c|}{ AR surface expression } \\
\hline$\beta_{2} \mathscr{C}$ & ت3 & 0 \\
\hline$\alpha_{1} \mathscr{R}$ & $\mathscr{2}^{2}$ & 20 \\
\hline+ & ++ & +++ \\
\hline
\end{tabular}

FIGURE 1 | Influence of alterations in circulating ovarian steroid levels in critical developmental periods on programming/reprogramming of thymic extrinsic and intrinsic adrenergic networks. This figure indicates (middle schemes) sex differences in noradrenaline content in noradrenergic nerve fibers and thymocytes, density of tyrosine hydroxylase (TH)-expressing ("adrenergic") cells, density of $\beta_{2}$-adrenoceptor (AR)+ thymic cells and thymocyte $\beta_{2}$-AR surface density in young adult rat thymus, and influence of (upper scheme) single injection of testosterone on the third postnatal day to female rats and (lower scheme) ovariectomy in peripubertal period on noradrenergic nerve fiber and thymic "adrenergic" cell density and their noradrenaline content, as well as the density of AR-expressing thymic cells and thymocyte AR surface density in young adult rats.

non-lymphoid cells. Thymic cells express $\beta_{2}$ - and $\alpha_{1}$-AR (67-70). Their expression is reciprocally regulated during thymocyte maturation $(50,71,72)$. The most mature $C D 3^{\text {high }}$ thymocytes predominantly express $\beta_{2}$-AR, whereas $\alpha_{1}$-AR expression is predominant on the most immature $\mathrm{CD}^{-}$thymocytes $(50,60,70$, 72). There is sexual diergism in the expression of $\beta_{2}$-AR on thymocytes. Immunophenotyping showed the higher frequency of $\beta_{2}$-AR-expressing cells among thymocytes from female compared 
with male young adult rats, but lower density of the receptor on their surface (73) (Figure 1). In addition, autoradiographic studies indicated a sexually dimorphic pattern of postnatal changes in the density of $\beta$-AR in rat thymus (69). There are no data on sex differences in $\alpha_{1}$-AR expression on thymocytes.

The expression of $\beta_{2}$-AR was also demonstrated on cortical (aminopeptidase $\mathrm{A}^{+}$), and medullary (UEA-1 ${ }^{+}$) TECs, CD68 ${ }^{+}$ macrophages, and $\mathrm{OX}_{62}{ }^{+}$dendritic cells (44). In addition, $\alpha_{1}$-AR-immunoreactive cells were observed among TECs and macrophages located predominantly in subcapsular/subtrabecular and corticomedullary thymic regions (60). Thymic dendritic cells also express $\alpha_{1}-\mathrm{AR}$ (74). The subsets of $\beta_{2}-\mathrm{AR}^{+}$and $\alpha_{1}-\mathrm{AR}^{+}$ non-lymphoid cells were shown to co-express TH (60). Thus, not only paracrine, but also autocrine noradrenaline action may be expected in the thymus.

\section{GONADAL STEROIDS AND PROGRAMMING/REPROGRAMMING OF THE THYMIC (NOR)ADRENERGIC NETWORKS AND AR EXPRESSION}

\section{Early Postnatal Thymic Programming}

The thymus is sexually differentiated organ (15). The sexual differentiation in the thymus, as in the brain areas controlling gonadotropin release, occurs during the critical perinatal period, and is governed by sex steroid-dependent mechanisms (15). In addition, the widely accepted organizational/activational hypotesis of the bran development is extended to encompass the thymic differentiation (15). According to the original hypothesis, in the absence of testicular androgens during the critical period (starting at the late prenatal period and continuing, at least, to day 5 postpartum), the areas controlling gonadotropin release develop in a primarily female manner (75-78). Conversely, the presence of testicular androgens leads to their defeminization/masculinization, a phenomenon known as neonatal androgenization (77-79). This postpones sexual maturation and leads to development of non-ovulatory ovaries with estrogen hyporesponsiveness (78, $80,81)$. The mechanisms of testosterone action in the brain and thymus are extremely complex, as in both organs it converts into estrogen $(15,75-78)$, and consequently does not act only through androgen receptors (82). The binding of estradiol to classical estrogen receptor (ER) $\alpha$ or ER $\beta$ in the cytoplasm of target cells causes the receptor dimerization and translocation in nucleus, where the dimer associates with various coactivators to enable binding to the estrogen response elements (EREs) in or near the promoters of target genes (83). Estradiol can also influence expression of genes that do not harbor EREs in their promoter regions. In this case, ligand-activated ERs do not bind DNA directly, but through protein-protein interactions with other classes of transcription factors at their respective response elements in promotor region of their target genes (84). In addition, estradiol may act through membrane G protein-coupled ER (GPER, previously termed GPR30) (84). This involves mobilization of diverse signaling pathways and may depend on a number of conditions, like the availability of signal transduction molecules and downstream targets (84).
It was shown that a single injection of testosterone on the third postnatal day enhanced thymic growth and postponed thymic involution in female rats, which normally starts around puberty (85, 86). Accordingly, long-lasting changes in thymopoiesis, mirrored in the enhanced thymocyte differentiation/maturation in adult animals were observed (86). In addition, neonatal androgenization facilitated the generation of $\mathrm{CD} 4^{-} \mathrm{CD} 8^{+} \mathrm{TCR} \alpha \beta^{\text {high }}$ cells, and consequently shifted $\mathrm{CD} 4^{+} / \mathrm{CD}^{+}$recent thymic emigrant ratio in peripheral blood toward the latter (86). The thymopoietic changes were ascribed to thymocyte overexpression of Thy-1, as its overexpression reduces thymocyte negative selection and favors maturation of $\mathrm{CD}^{+} \mathrm{T}$ cells (87). Considering $\mathrm{CD}^{+} \mathrm{T}$ cell dominance in the periphery of males when compared with females $(23,88)$, the previous findings indicate defeminization/masculinization of T-cell compartment in adult neonatally androgenized rats, i.e., speak in favor of a sex steroid role in the sexual differentiation of thymus.

Although aware of the complexity of changes in neuroendocrine-thymic communications in neonatally androgenized rats, in this review we focused on those mediated by catecholamines. Neonatal androgenization was shown to increase thymic noradrenaline concentration in adult rats (35). This mainly reflected the increase in nerve fiber noradrenaline content (35). Consistent with the so-called transsynaptic action of sex steroids on neurotransmitter synthesis (89), the previous finding may be explained by an augmented sympathetic tone in neonatally androgenized rats $(90,91)$. However, the higher noradrenaline concentration partly reflected the greater density of noradrenaline-synthesizing cells and noradrenaline content per cell (35) (Figure 1). Considering that the circulating level of testosterone was elevated in neonatally androgenized rats (35), this could be associated with data indicating that androgens prominently transactivate $\mathrm{TH}$ promoter (92). In light of data from other studies (51), the previous findings suggest thymic defeminization/masculinization in neonatally androgenized rats (Figure 1).

As additional sign of defeminization/masculinization (73), the frequency of $\beta_{2}$-AR-expressing cells within thymocytes (35) was diminished in neonatally androgenized rats (Figure 1). In addition, neonatal androgenization decreased $\beta_{2}$-AR density on thymocytes (35) (Figure 1). Given that in many cell types estrogen, acting through classical ERs, upregulates $\beta_{2}$-AR expression $(93,94)$, the alterations in $\beta_{2}$-AR density could reflect estrogen hyporesponsiveness $(80,95)$. This hyporesponsiveness most likely emerged from the ER interaction with an excess of estrogen (as a result of testosterone aromatization) during the critical period $(96,97)$. The interaction of receptor with excess ligand in the critical period is shown to cause misprinting substantiated in diminished receptor binding capacity and responsivity in later life $(96,97)$. The elevation of thymic noradrenaline concentration following the testosterone injection could also impair the efficacy of $\beta_{2}$-AR signaling (through the hormonal misprinting) (35), leading to the diminished noradrenaline action as the ultimate effect. In favor of this assumption is the increase in Thy- 1 expression in adult neonatally androgenized rats (83). Namely, the incubation of murine thymocytes with noradrenaline causes time- and concentration-dependent decreases in the Thy-1 mRNA levels, which 
are completely preventable by propranolol $(98,99)$. Moreover, given that: (i) noradrenaline upregulates $\alpha_{1}$-AR expression (100) and (ii) long-lasting $\alpha_{1}$-AR blockade facilitates thymocyte differentiation/maturation toward $\mathrm{CD} 4^{+} \mathrm{CD} 8^{-} \mathrm{TCR} \alpha \beta^{\text {high }}$ cells (70), the contribution of an augmented $\alpha_{1}-\mathrm{AR}$ signaling (reflecting its increased density and/or noradrenaline concentration) to the thymocyte maturation skewed toward $\mathrm{CD} 4^{-} \mathrm{CD} 8^{+} \mathrm{TCR} \alpha \beta^{\text {high }}$ cells in adult neonatally androgenized rats cannot be ruled out.

In favor of the role of sex steroids in perinatal programming of thymic noradrenergic networks are also data showing that orchidectomy in the critical perinatal period lowers levels of both neurally- and thymocyte-derived noradrenaline in adult rats and thereby contributes to the deceleration of the thymic involution (34). This is consistent with data indicating that not only in presence of excess ligand in the critical periods, but also in its absence the ligand-receptor connection changes for life (101).

To summarize, the previous findings indicate that alterations in circulating levels of sex steroids in the critical perinatal period may affect the programming of the sexually dimorphic (nor) adrenaline influence on thymopoiesis. However, the molecular mechanisms standing behind this phenomenon remain to be elucidated.

\section{Peripubertal Thymic Reprogramming}

It has been suggested that the hormonal changes occurring at the time of puberty lay the framework for biological differences that persist throughout life (102). In addition, the original organizational/activational hypothesis of sexual differentiation of the brain has been extended to include puberty $(76,103)$. Namely, ovariectomy in peripubertal period leads to a long-lasting postponement/alleviation of the postpubertal decline in thymopoiesis $(33,104)$. This could be partly related to ovariectomy-induced changes in thymocyte proliferation (35). Given that the agerelated decline in thymopoiesis has been partly related to the rise in the thymic noradrenaline level $(44,50,105)$, one may assume that the peripubertal ovariectomy affects thymic adrenergic networks. Indeed, it was shown that it diminishes the thymic noradrenaline level in young adult (2-month-old) rats (45). This reflected the decrease in the density of noradrenergic nerve fibers and noradrenaline content in both noradrenergic nerve fibers and non-lymphoid cells, as thymocyte noradrenaline content increased (45) (Figure 1). These changes were preventable by estrogen supplementation (45). This could be explained by the following facts: (i) estrogen represents the key factor in remodeling of noradrenergic innervation in some other tissues (106) and (ii) is implicated in the regulation of TH expression (107). Estrogen is suggested to regulate $\mathrm{TH}$ gene expression through direct genomic effects, as the TH promoter contains several elements, including the activation protein 1 and Sp1/Egr1 motifs that might mediate estrogen action on TH gene $(108,109)$. The thymic cell type-specific effects of peripubertal ovariectomy on TH expression could be explained by data indicating that estrogen may regulate $\mathrm{TH}$ transcription in opposite direction through $\mathrm{ER} \alpha$ and $\operatorname{ER} \beta$ (110). Given that estrogen may influence TH expression trough extragenomic and indirect genomic effects, it may also be supposed that estrogen, through the same ER, may produce opposing effects by interacting with proteins with distinct action on gene transcription in distinct cells $(111,112)$. In peripubertally ovariectomized rats, the density of noradrenergic nerve fibers and $\mathrm{TH}$-expressing non-lymphoid cells remained lower than in age-matched controls until the age of 11 months (45). On the other hand, thymocyte noradrenaline, which was elevated in 2-month-old peripubertally ovariectomized rats, continued to rise until the age of 11 months (45). In 11-month-old peripubertally ovariectomized rats it was comparable with controls (45). Thus, it seems that the ovariectomy-induced changes are long lasting (45).

In addition, peripubertal ovariectomy in young adult rats diminished the average thymocyte surface density of $\beta_{2}$-AR, but it increased that of $\alpha_{1}$-AR (reflecting estrogen, and estrogen and progesterone deficiency, respectively) (45) (Figure 1). These changes, despite the rise in circulating estrogen level postovariectomy because of extragonadal synthesis (113), remained stable until the age of 11 months (45). This could be related to a decreased sensitivity to estrogen action, as a consequence of peripubertal hormone misprinting. Finally, it is noteworthy that the increased noradrenaline content in thymocytes and diminished frequency of $\beta_{2}-\mathrm{AR}^{+}$thymocytes in young adult ovariectomized rats suggested that peripubertal ovariectomy instigates some signs of thymic defeminization/masculinization (51, 73) (Figure 1).

The putative role of peripubertal orchidectomy in longlasting reprogramming of the thymic adrenergic networks has not been examined. However, 1 month following peripubertal orchidectomy the changes in both extrinsic and intrinsic noradrenergic networks were similar to those described 1 month following ovariectomy in the same age $(44,45)$. In addition, an impaired $\beta$-AR-mediated influence on thymus led to more efficient thymocyte positive selection/less efficient negative selection, and preferential differentiation/maturation of thymocytes into mature $\mathrm{CD} 4^{+} \mathrm{CD} 8^{-} \mathrm{TCR} \alpha \beta^{\text {high }}$ cells in orchidectomized rats (44), i.e., to a more "feminine" pattern of T-cell development (23).

\section{CONCLUSION}

In summary, a growing body of evidence indicates that both thymic sexual differentiation and involution are, at least partly, "controlled" during the critical developmental periods by gonadal steroids. In addition, it suggests that the gonadal steroid-mediated thymic (re)programming involves extrinsic and intrinsic noradrenergic regulatory networks and $A R$ expression on thymic cells. The challenge remains to elucidate the molecular mechanisms underlying these gonadal steroidinduced effects. Nonetheless, it may be assumed that (i) alterations in circulating levels of gonadal steroids during the critical developmental periods (either induced endogenously or by endocrine disruptors in the environment) lead to long-lasting effects on thymopoiesis and (ii) pharmacological manipulation with (nor)adrenaline action on thymus may be useful means in preventing/moderating deleterious effects of aging on thymopoiesis. 


\section{AUTHOR CONTRIBUTIONS}

GL wrote the draft version, and IP designed the figure, whereas GL and IP equally contributed to the editing of this manuscript.

\section{REFERENCES}

1. Krueger A, Ziętara N, Łyszkiewicz M. T cell development by the numbers. Trends Immunol (2016) 38:128-39. doi:10.1016/j.it.2016.10.007

2. Rezzani R, Nardo L, Favero G, Peroni M, Rodella LF. Thymus and aging: morphological, radiological, and functional overview. Age (Dordr) (2014) 36:313-51. doi:10.1007/s11357-013-9564-5

3. Aw D, Palmer DB. It's not all equal: a multiphasic theory of thymic involution. Biogerontology (2012) 13:77-81. doi:10.1007/s10522-011-9349-0

4. Linton PJ, Dorshkind K. Age-related changes in lymphocyte development and function. Nat Immunol (2004) 5:133-9. doi:10.1038/ni1033

5. Goronzy JJ, Lee WW, Weyand CM. Aging and T-cell diversity. Exp Gerontol (2007) 42:400-6. doi:10.1016/j.exger.2006.11.016

6. Yager EJ, Ahmed M, Lanzer K, Randall TD, Woodland DL, Blackman MA. Age-associated decline in $\mathrm{T}$ cell repertoire diversity leads to holes in the repertoire and impaired immunity to influenza virus. J Exp Med (2008) 205:711-23. doi:10.1084/jem.20071140

7. Nikolich-Žugich J. Ageing and life-long maintenance of T-cell subsets in the face of latent persistent infections. Nat Rev Immunol (2008) 8:512-22. doi:10.1038/nri2318

8. Haynes L, Swain SL. Why aging T cells fail: implications for vaccination. Immunity (2006) 24:663-6. doi:10.1016/j.immuni.2006.06.003

9. Giefing-Kröll C, Berger P, Lepperdinger G, Grubeck-Loebenstein B. How sex and age affect immune responses, susceptibility to infections, and response to vaccination. Aging Cell (2015) 14:309-21. doi:10.1111/acel.12326

10. Fulop T, Kotb R, Fortin CF, Pawelec G, de Angelis F, Larbi A. Potential role of immunosenescence in cancer development. Ann N Y Acad Sci (2010) 1197:158-65. doi:10.1111/j.1749-6632.2009.05370.x

11. Foster AD, Sivarapatna A, Gress RE. The aging immune system and its relationship with cancer. Aging Health (2011) 7:707-18. doi:10.2217/ahe.11.56

12. Mackall CL, Punt JA, Morgan P, Farr AG, Gress RE. Thymic function in young/ old chimeras: substantial thymic T cell regenerative capacity despite irreversible age-associated thymicinvolution.EurJ Immunol(1998)28:1886-93.doi:10.1002/ (SICI)1521-4141(199806)28:06<1886::AID-IMMU1886>3.0.CO;2-M

13. Lynch HE, Goldberg GL, Chidgey A, Van den Brink MR, Boyd R, Sempowski GD. Thymic involution and immune reconstitution. Trends Immunol (2009) 30:366-73. doi:10.1016/j.it.2009.04.003

14. Gui J, Mustachio LM, Su DM, Craig RW. Thymus size and age-related thymic involution: early programming, sexual dimorphism, progenitors and stroma. Aging Dis (2012) 3:280-90.

15. de Fougerolles Nunn E, Greenstein B, Khamashta M, Hughes GR. Evidence for sexual dimorphism of estrogen receptors in hypothalamus and thymus of neonatal and immature Wistar rats. Int J Immunopharmacol (1999) 21:869-77. doi:10.1016/S0192-0561(99)00055-7

16. Leposavić G, Karapetrović B, Budeč M, Kosec D. Sex differences in the phenotypic characteristics of rat thymocytes. Acta Vet (Beogr) (1995) 45:205-10.

17. Leposavić G, Karapetrović B, Obradović S, Vidić Danković B, Kosec D. Differential effects of gonadectomy on the thymocyte phenotypic profile in male and female rats. Pharmacol Biochem Behav (1996) 54:269-76. doi:10.1016/0091-3057(95)02165-5

18. Pido-Lopez J, Imami N, Aspinall R. Both age and gender affect thymic output: more recent thymic migrants in females than males as they age. Clin Exp Immunol (2001) 125:409-13. doi:10.1046/j.1365-2249.2001. 01640.x

19. Gubbels Bupp MR. Sex, the aging immune system, and chronic disease. Cell Immunol (2015) 294:102-10. doi:10.1016/j.cellimm.2015.02.002

20. Dumont-Lagacé M, St-Pierre C, Perreault C. Sex hormones have pervasive effects on thymic epithelial cells. Sci Rep (2015) 5:12895. doi:10.1038/ srep 12895

\section{FUNDING}

The study was supported by the Ministry of Education, Science and Technological Development of the Republic of Serbia (Grant No. 175050).

21. Nagakubo D, Krauth B, Boehm T. Genetic and non-genetic determinants of thymic epithelial cell number and function. Sci Rep (2017) 7:10314. doi:10.1038/s41598-017-10746-8

22. Mitchell WA, Lang PO, Aspinall R. Tracing thymic output in older individuals. ClinExpImmunol (2010) 161:497-503.doi:10.1111/j.1365-2249.2010.04209.x

23. Olsen NJ, Kovacs WJ. Gonadal steroids and immunity. Endocr Rev (1996) 17:369-84. doi:10.1210/edrv-17-4-369

24. Klein SL, Flanagan KL. Sex differences in immune responses. Nat Rev Immunol (2016) 16:626-38. doi:10.1038/nri.2016.90

25. Aspinall R, Andrew D. Gender-related differences in the rates of age associated thymic atrophy. Dev Immunol (2001) 8:95-106. doi:10.1155/2001/17064

26. Saito M, Amo H, Murakumo Y, Kojima A, Katoh H, Hiromatsu T, et al. Genetically determined thymus enlargement in the early life in BUF/Mna rats. Tohoku J Exp Med (1997) 182:309-18. doi:10.1620/tjem.182.309

27. Belyaev DK, Gruntenko EV. Strain differences in thymus weight in mice with different predispositions to spontaneous mammary cancer. Nature (1972) 237:401-2. doi:10.1038/237401a0

28. Peleg L, Nesbitt MN. Genetic control of thymus size in inbred mice. J Hered (1984) 75:126-30. doi:10.1093/oxfordjournals.jhered.a109886

29. Hsu HC, Zhang HG, Li L, Yi N, Yang PA, Wu Q, et al. Age-related thymic involution in $\mathrm{C} 57 \mathrm{BL} / 6 \mathrm{~J} \times \mathrm{DBA} / 2 \mathrm{~J}$ recombinant-inbred mice maps to mouse chromosomes 9 and 10. Genes Immun (2003) 4:402-10. doi:10.1038/ sj.gene.6363982

30. Wang X, Hsu HC, Wang Y, Edwards CK, Yang P, Wu Q, et al. Phenotype of genetically regulated thymic involution in young BXD RI strains of mice. Scand J Immunol (2006) 64:287-94. doi:10.1111/j.1365-3083.2006.01813.x

31. Gui J, Morales AJ, Maxey SE, Bessette KA, Ratcliffe NR, Kelly JA, et al. MCL1 increases primitive thymocyte viability in female mice and promotes thymic expansion into adulthood. Int Immunol (2011) 23:647-59. doi:10.1093/ intimm/dxr073

32. Calder PC, Krauss-Etschmann S, de Jong EC, Dupont C, Frick JS, Frokiaer $\mathrm{H}$, et al. Early nutrition and immunity-progress and perspectives. Br J Nutr (2006) 96:774-90. doi:10.1079/BJN20061881

33. Leposavić G, Perisić M. Age-associated remodeling of thymopoiesis: role for gonadal hormones and catecholamines. Neuroimmunomodulation (2008) 15:290-322. doi:10.1159/000156473

34. Leposavić G, Radojević K, Vidić-Danković B, Kosec D, Pilipović I, Perisić M. Early postnatal castration affects thymic and thymocyte noradrenaline levels and beta-adrenoceptor-mediated influence on the thymopoiesis in adult rats. J Neuroimmunol (2007) 182:100-15. doi:10.1016/j.jneuroim.2006. 10.004

35. Radojević K, Kosec D, Perišić M, Pilipović I, Vidić-Danković B, Leposavić G. Neonatal androgenization affects the efficiency of $\beta$-adrenoceptor-mediated modulation of thymopoiesis. J Neuroimmunol (2011) 239:68-79. doi:10.1016/j.jneuroim.2011.08.020

36. Williams JM, Felten DL. Sympathetic innervation of murine thymus and spleen: a comparative histofluorescence study. Anat Rec (1981) 199:531-42. doi:10.1002/ar.1091990409

37. Leposavić G, Mićić M, Ugresić N, Bogojević M, Isaković K. Components of sympathetic innervation of the rat thymus during late fetal and postnatal development: histofluorescence and biochemical study. Thymus (1992) 19:77-87.

38. Vizi ES, Orso E, Osipenko ON, Hasko G, Elenkov IJ. Neurochemical, electrophysiological and immunocytochemical evidence for a noradrenergic link between the sympathetic nervous system and thymocytes. Neuroscience (1995) 68:1263-76. doi:10.1016/0306-4522(95)00215-5

39. Kurz B, Feindt J, von Gaudecker B, Kranz A, Loppnow H, Mentlein R. $\beta$-Adrenoceptor mediated effects in rat cultured thymic epithelial cells. $\mathrm{Br}$ J Pharmacol (1997) 120:1401-8. doi:10.1038/sj.bjp.0701045 
40. Novotny GE, Sommerfeld H, Zirbes T. Thymic innervation in the rat: a light and electron microscopical study. J Comp Neurol (1990) 302:552-61. doi:10.1002/cne.903020311

41. Artico M, Cavallotti C, Cavallotti D. Adrenergic nerve fibres and mast cells: correlation in rat thymus. Immunol Lett (2002) 84:69-76. doi:10.1016/ S0165-2478(02)00145-1

42. Leposavić G, Pilipović I, Radojević K. Immunomodulatory role of noradrenergic neural and non-neural system: role for $\beta$-adrenoceptor-mediated mechanisms in regulation of T-lymphocyte development. In: Endo M, Matsumoto N, editors. Beta Blockers: New Research. New York: Nova Science Publishers (2008). p. 141-82.

43. Singh U. Sympathetic innervation of fetal mouse thymus. Eur J Immunol (1984) 14:757-9. doi:10.1002/eji.1830140817

44. Pilipović I, Radojević K, Kosec D, Perišić Nanut M, Stojić-Vukanić Z, Arsenović-Ranin N, et al. Gonadal hormone dependent developmental plasticity of catecholamine: $\beta 2$-adrenoceptor signaling complex in male rat thymus: putative implications for thymopoiesis. J Neuroimmunol (2013) 265:20-35. doi:10.1016/j.jneuroim.2013.09.021

45. Pilipović I, Vujnović I, Arsenović-Ranin N, Dimitrijević M, Kosec D, Stojić-Vukanić Z, et al. Peripubertal ovariectomy influences thymic adrenergic network plasticity in adult rats. J Neuroimmunol (2016) 297:103-16. doi:10.1016/j.jneuroim.2016.05.017

46. Bellinger DL, Felten SY, Felten DL. Maintenance of noradrenergic sympathetic innervation in the involuted thymus of the aged Fischer 344 rat. Brain Behav Immun (1988) 2:133-50. doi:10.1016/0889-1591(88)90014-1

47. Mićić M, Leposavić G, Ugrešić N. Relationships between monoaminergic and cholinergic innervation of the rat thymus during aging. J Neuroimmunol (1994) 49:205-12. doi:10.1016/0165-5728(94)90197-X

48. Madden KS, Bellinger DL, Felten SY, Snyder E, Maida ME, Felten DL. Alterations in sympathetic innervation of thymus and spleen in aged mice. Mech Ageing Dev (1998) 94:165-75. doi:10.1016/S0047-6374(96)01858-1

49. Cavallotti C, Artico M, Cavallotti D. Occurrence of adrenergic nerve fibers and of noradrenaline in thymus gland of juvenile and aged rats. Immunol Lett (1999) 70:53-62. doi:10.1016/S0165-2478(99)00127-3

50. Leposavić G, Pešić P, Stojić-Vukanić Z, Radojević K, Arsenović-Ranin $\mathrm{N}$, Kosec D, et al. Age-associated plasticity of $\alpha 1$-adrenoceptor-mediated tuning of T-cell development. Exp Gerontol (2010) 45:918-35. doi:10.1016/ j.exger.2010.08.011

51. Pilipović I, Vidić-Danković B, Perišić M, Radojević K, Čolić M, Todorović V, et al. Sexual dimorphism in the catecholamine-containing thymus microenvironment: a role for gonadal hormones. J Neuroimmunol (2008) 195:7-20. doi:10.1016/j.jneuroim.2007.12.006

52. Bergquist J, Tarkowski A, Ekman R, Ewing A. Discovery of endogenous catecholamines in lymphocytes and evidence for catecholamine regulation of lymphocyte function via an autocrine loop. Proc Natl Acad Sci U S A (1994) 91:12912-6. doi:10.1073/pnas.91.26.12912

53. Cosentino M, Bombelli R, Ferrari M, Marino F, Rasini M, Maestroni GJ, et al. HPLC-ED measurement of endogenous catecholamines in human immune cells and hematopoietic cell lines. Life Sci (2000) 68:283-95. doi:10.1016/ S0024-3205(00)00937-1

54. Qiu YH, Peng YP, Jiang JM, Wang JJ. Expression of tyrosine hydroxylase in lymphocytes and effect of endogenous catecholamines on lymphocyte function. Neuroimmunomodulation (2004) 11:75-83. doi:10.1159/000075316

55. Radojević K, Rakin A, Pilipović I, Kosec D, Djikić J, Bufan B, et al. Effects of catecholamines on thymocyte apoptosis and proliferation depend on thymocyte microenvironment. J Neuroimmunol (2014) 272:16-28. doi:10.1016/j. jneuroim.2014.04.010

56. Takahama Y. Journey through the thymus: stromal guides for T-cell development and selection. Nat Rev Immunol (2006) 6:127-35. doi:10.1038/nri1781

57. Botham CA, Jones GV, Kendall MD. Immuno-characterisation of neuroendocrine cells of the rat thymus gland in vitro and in vivo. Cell Tissue Res (2001) 303:381-9. doi:10.1007/s004410000185

58. Jones GV, Botham CA, Clarke AG, Kendall MD. Immunoreactivity of neural crest-derived cells in thymic tissue developing under the rat kidney capsule. Brain Behav Immun (1998) 12:163-80. doi:10.1006/brbi.1998.0528

59. Anagnostou VK, Doussis-Anagnostopoulou I, Tiniakos DG, Karandrea D, Agapitos E, Karakitsos P, et al. Ontogeny of intrinsic innervation in the human thymus and spleen. J Histochem Cytochem (2007) 55:813-20. doi:10.1369/jhc.6A7168.2007
60. Leposavić G, Pilipović I, Radojević K, Pešić V, Perisić M, Kosec D. Catecholamines as immunomodulators: a role for adrenoceptor-mediated mechanisms in fine tuning of T-cell development. Auton Neurosci (2008) 144:1-12. doi:10.1016/j.autneu.2008.09.003

61. Huang MH, Bahl JJ, Wu Y, Hu F, Larson DF, Roeske WR, et al. Neuroendocrine properties of intrinsic cardiac adrenergic cells in fetal rat heart. Am J Physiol Heart Circ Physiol (2005) 288:497-503. doi:10.1152/ajpheart.00591.2004

62. Huang MH, Friend DS, Sunday ME, Singh K, Haley K, Austen KF, et al. An intrinsic adrenergic system in mammalian heart. J Clin Invest (1996) 98:1298-303. doi:10.1172/JCI118916

63. Miller LE, Grifka J, Schölmerich J, Straub RH. Norepinephrine from synovial tyrosine hydroxylase positive cells is a strong indicator of synovial inflammation in rheumatoid arthritis. J Rheumatol (2002) 29:427-35.

64. Kvetnansky R, Sabban EL, Palkovits M. Catecholaminergic systems in stress: structural and molecular genetic approaches. Physiol Rev (2009) 89:535-606. doi:10.1152/physrev.00042.2006

65. Tamura Y, Sano M, Nakamura H, Ito K, Sato Y, Shinmura K, et al. Neural crest-derived resident cardiac cells contribute to the restoration of adrenergic function of transplanted heart in rodent. Cardiovasc Res (2016) 109:350-7. doi:10.1093/cvr/cvv267

66. Capellino S, Weber K, Gelder M, Härle P, Straub RH. First appearance and location of catecholaminergic cells during experimental arthritis and elimination by chemical sympathectomy. Arthritis Rheum (2012) 64:1110-8. doi:10.1002/art.33431

67. Marchetti B, Morale MC, Pelletier G. The thymus gland as a major target for the central nervous system and the neuroendocrine system: neuroendocrine modulation of thymic $\beta 2$-adrenergic receptor distribution as revealed by in vitro autoradiography. Mol Cell Neurosci (1990) 1:10-9. doi:10.1016/1044-7431(90)90037-5

68. Marchetti B, Morale MC, Pelletier G. Sympathetic nervous system control of thymus gland maturation: autoradiographic characterization and localization of the $\beta 2$-adrenergic receptors in the rat thymus gland and presence of a sexual dimorphism during ontogenic development. Prog Neuroendocr Immunol (1990) 3:103-15.

69. Marchetti B, Morale MC, Paradis P, Bouvier M. Characterization, expression, and hormonal control of a thymic beta 2-adrenergic receptor. Am J Physiol Endocrinol Metab (1994) 267:718-31. doi:10.1152/ajpendo.1994.267.5.E718

70. Pesić V, Kosec D, Radojević K, Pilipović I, Perisić M, Vidić-Danković B, et al Expression of alpha1-adrenoceptors on thymic cells and their role in fine tuning of thymopoiesis. J Neuroimmunol (2009) 214:55-66. doi:10.1016/ j.jneuroim.2009.06.018

71. Fuchs BA, Albright JW, Albright JF. $\beta$-Adrenergic receptors on murine lymphocytes: density varies with cell maturity and lymphocyte subtype and is decreased after antigen administration. Cell Immunol (1988) 114:231-45. doi:10.1016/0008-8749(88)90318-8

72. Kavelaars A. Regulated expression of alpha-1 adrenergic receptors in the immune system. Brain Behav Immun (2002) 16:799-807. doi:10.1016/ S0889-1591(02)00033-8

73. Leposavić G, Pilipović I, Perišić M. Cellular and nerve fibre catecholaminergic thymic network: steroid hormone dependent activity. Physiol Res (2011) 60:S71-S82.

74. Leposavić G, Pilipović I, Perišić M. Age-associated remodeling of neural and nonneural thymic catecholaminergic network affects thymopoietic productivity. Neuroimmunomodulation (2011) 18:290-308. doi:10.1159/000329499

75. Mackinnon PCB, Greenstein BD. Sexual differentiation of the brain. In: Faulkner F, Tanner JM, editors. Human Growth. A Comprehensive Treatise. Vol. 2: Postnatal Growth; Neurobiology. New York: Plenum Publishing Corporation (1986). p. 437-68.

76. Phoenix CH, Goy RW, Gerall AA, Young WC. Organizing action of prenatally administered testosterone propionate on the tissues mediating mating behavior in the female guinea pig. Endocrinology (1959) 65:369-82. doi:10.1210/endo-65-3-369

77. Gorski RA. Sexual differentiation of the hypothalamus. In: Mack H, Sherman AI, editors. The Neuroendocrinology of Human Reproduction. Springfield: CC Thomas Publisher (1971). p. 60-90.

78. Arai Y, Matsumoto A, Nishizuka M. Synaptogenesis and neuronal plasticity to gonadal steroids: implication for the development of sexual dimorphism in the neuroendocrin brain. In: Ganten D, Pfaff D, editors. Current Topics in Neuroendocrinology. Berlin: Springer (1986). p. 291-307. 
79. Gorski RA, Gordon JH, Shryne JE, Southam AM. Evidence for a morphological sex difference within the medial preoptic area of the rat brain. Brain Res (1978) 148:333-46. doi:10.1016/0006-8993(78)90723-0

80. Tang FY, Bonfiglio TA, Tang LK. Effect of estrogen and progesterone on the development of endometrial hyperplasia in the Fischer rat. Biol Reprod (1984) 31:399-413. doi:10.1095/biolreprod31.2.399

81. Barraclough CA. Production of anovulatory, sterile rats by single injections of testosterone propionate. Endocrinology (1961) 68:62-7. doi:10.1210/ endo-68-1-62

82. Thomas P, Pang Y, Dong J, Berg AH. Identification and characterization of membrane androgen receptors in the ZIP9 zinc transporter subfamily: II. Role of human ZIP9 in testosterone-induced prostate and breast cancer cell apoptosis. Endocrinology (2014) 155:4250-65. doi:10.1210/en.2014-1201

83. McCarthy MM. Estradiol and the developing brain. Physiol Rev (2008) 88:91-124. doi:10.1152/physrev.00010.2007

84. Filardo EJ, Thomas P. Minireview: G protein-coupled estrogen receptor-1, GPER-1: its mechanism of action and role in female reproductive cancer, renal and vascular physiology. Endocrinology (2012) 153:2953-62. doi:10.1210/en.2012-1061

85. Leposavić G, Pejčić-Karapetrovic B, Kosec D. Neonatal androgenization affects the intrathymic T-cell maturation in rats. Neuroimmunomodulation (2005) 12:117-30. doi:10.1159/000083584

86. Leposavić G, Perisić M, Kosec D, Arsenović-Ranin N, Radojević K, Stojić-Vukanić Z, et al. Neonatal testosterone imprinting affects thymus development and leads to phenotypic rejuvenation and masculinization of the peripheral blood T-cell compartment in adult female rats. Brain Behav Immun (2009) 23:294-304. doi:10.1016/j.bbi.2008.11.002

87. Hueber AO, Bernard AM, Battari CL, Marguet D, Massol P, Foa C, et al. Thymocytes in Thy-1-/- mice show augmented TCR signaling and impaired differentiation. Curr Biol (1997) 7:705-8. doi:10.1016/S0960-9822(06) 00300-9

88. Shames RS. Gender differences in the development and function of the immune system. JAdolesc Health (2002) 30:59-70. doi:10.1016/ S1054-139X(01)00382-2

89. Alonso-Solís R, Abreu P, López-Coviella I, Hernández G, Fajardo N, Hernández-Díaz F, et al. Gonadal steroid modulation of neuroendocrine transduction: a transynaptic view. Cell Mol Neurobiol (1996) 16:357-82. doi:10.1007/BF02088101

90. Simerly RB. Hormonal control of the development and regulation of tyrosine hydroxylase expression within a sexually dimorphic population of dopaminergic cells in the hypothalamus. Brain Res Mol Brain Res (1989) 6:297-310. doi:10.1016/0169-328X(89)90075-2

91. Plut C, Ribiere C, Giudicelli Y, Dausse JP. Gender differences in hypothalamic tyrosine hydroxylase and alpha(2)-adrenoceptor subtype gene expression in cafeteria diet-induced hypertension and consequences of neonatal androgenization. J Pharmacol Exp Ther (2002) 302:525-31. doi:10.1124/ jpet.302.2.525

92. Jeong H, Kim MS, Kwon J, Kim KS, Seol W. Regulation of the transcriptional activity of the tyrosine hydroxylase gene by androgen receptor. Neurosci Lett (2006) 396:57-61. doi:10.1016/j.neulet.2005.11.011

93. Moawad AH, River LP, Kilpatrick SJ. The effect of estrogen and progesterone on beta-adrenergic receptor activity in rabbit lung tissue. Am J Obstet Gynecol (1982) 144:608-13. doi:10.1016/0002-9378(82)90235-6

94. Wu Q, Zhao Z, Sun H, Hao YL, Yan CD, Gu SL. Oestrogen changed cardiomyocyte contraction and beta-adrenoceptor expression in rat hearts subjected to ischaemia-reperfusion. Exp Physiol (2008) 93:1034-43. doi:10.1113/ expphysiol.2007.041939

95. Arner P. Effects of testosterone on fat cell lipolysis. Species differences and possible role in polycystic ovarian syndrome. Biochimie (2005) 87:39-43. doi:10.1016/j.biochi.2004.11.012

96. Csaba G, Dobozy O, Inczefi-Gonda A, Szeberenyi S. Effect of the absence of neonatal testosterone imprinting on the activity of the microsomal enzyme system and on the dexamethasone binding of the thymus in adulthood. Acta Physiol Hung (1988) 71:421-7.

97. Csaba G, Inczefi-Gonda A. Effect of a single treatment (imprinting) with genistein or combined treatment with genistein+benzpyrene on the binding capacity of glucocorticoid and estrogen receptors of adult rats. Hum Exp Toxicol (2002) 21:231-4. doi:10.1191/0960327102ht242oa

98. Wajeman-Chao SA, Lancaster SA, Graf LH Jr, Chambers DA. Mechanism of catecholamine-mediated destabilization of messenger RNA encoding Thy-1 protein in T-lineage cells. J Immunol (1998) 161:4825-33.

99. Lajevic MD, Koduvayur SP, Caffrey V, Cohen RL, Chambers DA. Thy-1 mRNA destabilization by norepinephrine a $3^{\prime}$ UTR cAMP responsive decay element and involves RNA binding proteins. Brain Behav Immun (2010) 24:1078-88. doi:10.1016/j.bbi.2010.04.006

100. Kikuchi-Utsumi K, Kikuchi-Utsumi M, Cannon B, Nedergaard J. Differential regulation of the expression of alpha1-adrenergic receptor subtype genes in brown adipose tissue. Biochem J (1997) 322:417-24. doi:10.1042/bj3220417

101. Csaba G. The biological basis and clinical significance of hormonal imprinting, an epigenetic process Clin Epigenetics (2011) 2:187-96. doi:10.1007/ s13148-011-0024-8

102. Da Silva JAP. Sex hormones and glucocorticoids: interactions with the immune system. Ann N Y Acad Sci (1999) 876:102-17. doi:10.111 1/j.1749-6632.1999.tb07628.x

103. Schulz KM, Molenda-Figueira HA, Sisk CL. Back to the future: the organizational-activational hypothesis adapted to puberty and adolescence. Horm Behav (2009) 55:597-604. doi:10.1016/j.yhbeh.2009.03.010

104. Perišić M, Kosec D, Pilipović I, Radojević K, Pešić V, Rakin A, et al. Peripubertal ovariectomy provides long-term postponement of age-associated decline in thymic cellularity and T-cell output. Acta Vet (Beogr) (2009) 59:3-15. doi:10.2298/AVB0901003P

105. ThyagaRajan S, Madden KS, Teruya B, Stevens SY, Felten DL, Bellinger DL. Age-associated alterations in sympathetic noradrenergic innervation of primary and secondary lymphoid organs in female Fischer 344 rats. J Neuroimmunol (2011) 233:54-64. doi:10.1016/j.jneuroim.2010.11.012

106. Chávez-Genaro R, Crutcher K, Viettro L, Richeri A, Coirolo N, Burnstock $\mathrm{G}$, et al. Differential effects of oestrogen on developing and mature uterine sympathetic nerves. Cell Tissue Res (2002) 308:61-73. doi:10.1007/ s00441-002-0521-3

107. Thanky NR, Son JH, Herbison AE. Sex differences in the regulation of tyrosine hydroxylase gene transcription by estrogen in the locus coeruleus of TH9-LacZ transgenic mice. Brain Res Mol Brain Res (2002) 104:220-6. doi:10.1016/S0169-328X(02)00383-2

108. Nakashima A, Ota A, Sabban EL. Interactions between Egrl and AP1 factors in regulation of tyrosine hydroxylase transcription. Brain Res Mol Brain Res (2003) 112:61-9. doi:10.1016/S0169-328X(03)00047-0

109. Fung BP, Yoon SO, Chikaraishi DM. Sequences that direct rat tyrosine hydroxylase gene expression. J Neurochem (1992) 58:2044-52. doi:10.111 1/j.1471-4159.1992.tb10945.x

110. McDonnell DP, Norris JD. Connections and regulation of the human estrogen receptor. Science (2002) 296:1642-4. doi:10.1126/science.1071884

111. Serova LI, Maharjan S, Huang A, Sun D, Kaley G, Sabban EL. Response of tyrosine hydroxylase and GTP cyclohydrolase I gene expression to estrogen in brain catecholaminergic regions varies with mode of administration. Brain Res (2004) 1015:1-8. doi:10.1016/j.brainres.2004.04.002

112. Raab H, Pilgrim C, Reisert I. Effects of sex and estrogen on tyrosine hydroxylase mRNA in cultured embryonic rat mesencephalon. Brain Res Mol Brain Res (1995) 33:157-64. doi:10.1016/0169-328X(95)00125-C

113. Zhao H, Tian Z, Hao J, Chen B. Extragonadal aromatization increases with time after ovariectomy in rats. Reprod Biol Endocrinol (2005) 3:6. doi:10.1186/1477-7827-3-6

Conflict of Interest Statement: The authors declare that they have not any commercial or financial relationships that could be construed as a potential conflict of interest.

Copyright $\odot 2018$ Leposavić and Pilipović. This is an open-access article distributed under the terms of the Creative Commons Attribution License (CC BY). The use, distribution or reproduction in other forums is permitted, provided the original author(s) and the copyright owner are credited and that the original publication in this journal is cited, in accordance with accepted academic practice. No use, distribution or reproduction is permitted which does not comply with these terms. 